\title{
ANOMALOUS HALL EFFECT AND TRANSPORT PROPERTIES OF ULTRA-THIN $\mathrm{Fe}_{65} \mathrm{Co}_{35}$ FILMS
}

\author{
NEPRAVILEN HALLOV EFEKT IN TRANSPORTNE LASTNOSTI \\ ULTRATANKIH Fe 65 Co35 FILMOV
}

\author{
Hui Li*, Yemei Han, Xianming Ren, Zhi Tao, Kailiang Zhang \\ School of Electrical and Electronic Engineering, Tianjin Key Laboratory of Film Electronic \& Communication Devices, Tianjin University \\ of Technology, Tianjin 300384, China \\ Prejem rokopisa - received: 2019-10-29; sprejem za objavo - accepted for publication: 2020-03-23
}

doi:10.17222/mit.2019.259

\begin{abstract}
We report on the preparation of nanoscale ultra-thin $\mathrm{Fe}_{65} \mathrm{Co}_{35}$ films of different thicknesses applied on $\mathrm{Si} / \mathrm{SiO} \mathrm{O}_{2}$ substrates with ion-beam deposition. Grazing incidence X-ray diffraction (GIXRD) was employed to characterize the microstructure of the $\mathrm{Fe}_{65} \mathrm{Co}_{35}$ films. Magnetic hysteresis loops of the $\mathrm{Fe}_{65} \mathrm{Co}_{35}$ films indicate good soft-magnetic properties of the films. We measured the transport properties of the films, and the behavior of resistance switching for more than an order of magnitude was obtained. The measurement performed on the ultra-thin $\mathrm{Fe}_{65} \mathrm{Co}_{35}$ films reveal that the resistance-switching behavior is reversible and the transformation occurs between two stable resistant states. The modulation can be attributed to the anomalous Hall effect and the modification of the charge-carrier density at the interface.

Keywords: ferromagnetic film, resistance switching, anomalous Hall effect, carrier density
\end{abstract}

Avtorji v prispevku poročajo o ultratankih filmih $\mathrm{Fe}_{65} \mathrm{Co}_{35}$, različnih debelin in z različno nanostrukturo, ki so pripravljeni z nanosom v ionskem curku. Za karakterizacijo $\mathrm{Fe}_{65} \mathrm{Co}_{35}$ filmov so uporabili difrakcijsko metodo obstreljevanja $\mathrm{z}$ rentgenskimi žarki (GIXRD; angl: grazing incidence X-ray diffraction). Magnetne histerezne zanke izdelanih filmov dokazujejo njihove dobre magnetne lastnosti. Izmerili so transportne lastnosti filmov in obnašanje med uporovnim preklapljanjem, ki je bilo za več kot red velikosti večje. Na filmih izvedene meritve so pokazale, da je uporovno preklapljanje reverzibilno in pretvorba poteka med dvema stabilnima uporovnima stanjema. Manipulacijo pripisujejo nepravilnemu Hallovemu efektu in modifikaciji gostote nosilcev naboja na mejni ploskvi.

Ključne besede: feromagnetni film, uporovno preklapljanje, nepravilen Hallov efekt gostota nosilcev naboja

\section{INTRODUCTION}

In the field of spintronics, research on electronically controlled magnetism has received much attention. ${ }^{1}$ The coupling of resistance switching and magnetism is a typical example of electric control. ${ }^{2}$ Under the action of electric field, a dual control of resistance and magnetism of a device is realized. ${ }^{3}$ If resistance switching and magnetic switching are integrated in one device, the storage density of data can be greatly improved, and a multilevel storage of data can be realized. ${ }^{4}$ In a recent study, N. Spaldin et al..$^{5}$ explained the possibility of using an electric field to directly adjust the magnetic properties of magnetic materials. The results show that the magnetoelectric coupling effect can be realized without the need of an insulating layer, and a metal non-volatile memory can be constructed using the electromagnetic change of the Fe film. ${ }^{6}$ The Curie temperature of ferromagnetic metals and some alloys is higher than room temperature, ${ }^{7}$ and the direct modulation of magnetic properties with an electric field is of great significance for the realization of new memory devices. ${ }^{8}$ However, due to the electrostatic shielding of the metal under an electric field, the induced

*Corresponding author's e-mail:

740293354@qq.com (Hui Li) charge of the metal surface prevents the electric field from entering the inside of the conductor. ${ }^{9}$ The electric field can only exist at the atomic scale of the surface. ${ }^{10}$ Therefore, in an ultra-thin ferromagnetic metal film, the electric field may modulate the carrier density and electron configuration of the film, ${ }^{11}$ thus modulating the macroscopic magnetic properties. ${ }^{12}$ In this work, we report on the fabrication of ferromagnetic structures consisting of $\mathrm{Fe}_{65} \mathrm{Co}_{35}$ thin films grown on $\mathrm{Si} / \mathrm{SiO}_{2}$ substrates. We discuss the resistance-switching behavior and transition mechanism of ferromagnetic metal films.

\section{EXPERIMENTAL PART}

An $\mathrm{Fe}_{65} \mathrm{Co}_{35}$ alloy target was used and a thin film was deposited on a $\mathrm{SiO}_{2} / \mathrm{Si}$ substrate using ion-beam deposition. The film was deposited under a discharge voltage of $60 \mathrm{~V}$, acceleration voltage of $200 \mathrm{~V}$ and beam voltage of $0.5 \mathrm{Kv}$. During the deposition process, argon gas was continuously injected and its flow was maintained at $5.7 \mathrm{~cm}^{3} / \mathrm{min}$. Thin films with thicknesses of $(2,5,10,15$ and 20) $\mathrm{nm}$ were deposited. The microstructures of the prepared films were characterized with grazing incidence X-ray diffraction (GIXRD, BrookeD8, Advance). An electron probe micro-analyzer (EPMA, JXA-8230) was 
used for the elemental-composition analysis. A vibrating-sample magnetometer (VSM, Lake Shore 7404) was used to analyze the magnetic properties of the films. A semiconductor device analyzer (B1500A) was used to analyze the resistance-switching behavior. Transport properties were measured using the physical-property measurement system (ppms-9).

\section{RESULTS AND DICUSSION}

Figure 1 shows the grazing incidence XRD diffraction patterns of the $\mathrm{Fe}_{65} \mathrm{CO}_{35}$ films with different thicknesses. Since the films were very thin, we used the grazing incidence method to characterize the crystal structure of the ultra-thin $\mathrm{Fe}_{65} \mathrm{Co}_{35}$ films. The bodycentered cubic structure (bcc) of FeCo (110) was indexed from the diffraction peak that appeared near $45^{\circ}$. By comparison, it was found that as the thickness of the films increases from $2 \mathrm{~nm}$ to $20 \mathrm{~nm}$, the diffraction peak near $45^{\circ}$ becomes sharper, indicating that the film crystallinity is increasing. In addition, the EPMA test result showed that the $\mathrm{Fe}$ content in the $\mathrm{Fe}_{65} \mathrm{Co}_{35}$ film was about $65 \%$, and the Co content was about $35 \%$.

Figure 2 shows hysteresis loops for the $\mathrm{Fe}_{65} \mathrm{Co}_{35}$ thin films with thicknesses of $(5,10,15$ and 20) nm, while hysteresis loops are absent in the 2-nm thin films due to their thinness. It was found that with the increase in film thickness, the saturation-magnetization intensity gradually increased, and it was $(0.76,1.12,2.01$ and 2.11$)$ $\mathrm{emu} / \mathrm{mm}^{3}$, for $(5,10,15$ and 20$) \mathrm{nm} \mathrm{Fe}_{65} \mathrm{Co}_{35}$ films, respectively. The $\mathrm{Fe}_{65} \mathrm{Co}_{35}$ films exhibited coercive-force values of about $(38,41,47$ and 50) Gauss for $(5,10,15$ and 20) $\mathrm{nm} \mathrm{Fe}_{65} \mathrm{Co}_{35}$ films, respectively, confirming that the prepared $\mathrm{Fe}_{65} \mathrm{Co}_{35}$ films had good soft-magnetic characteristics.

Curves $\mathrm{I}-\mathrm{V}$ of the $\mathrm{Fe}_{65} \mathrm{Co}_{35}$ thin films were obtained. Figure 3 illustrates these curves of the $\mathrm{Fe}_{65} \mathrm{Co}_{35}$ films with thickness of $(5,10,15$ and 20) nm. The current as a

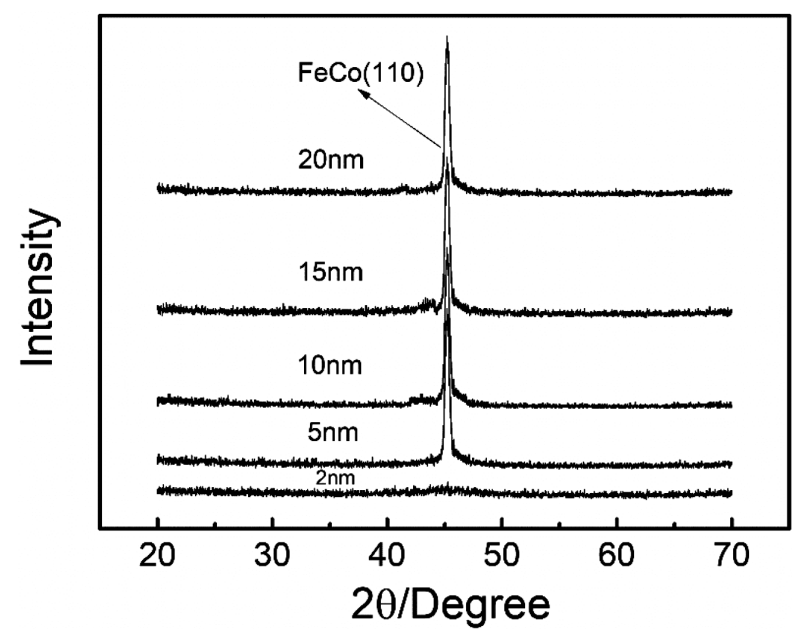

Figure 1: Grazing incidence XRD patterns for $(2,5,10,15$ and 20) $\mathrm{nm} \mathrm{Fe}_{65} \mathrm{Co}_{35}$ thin films

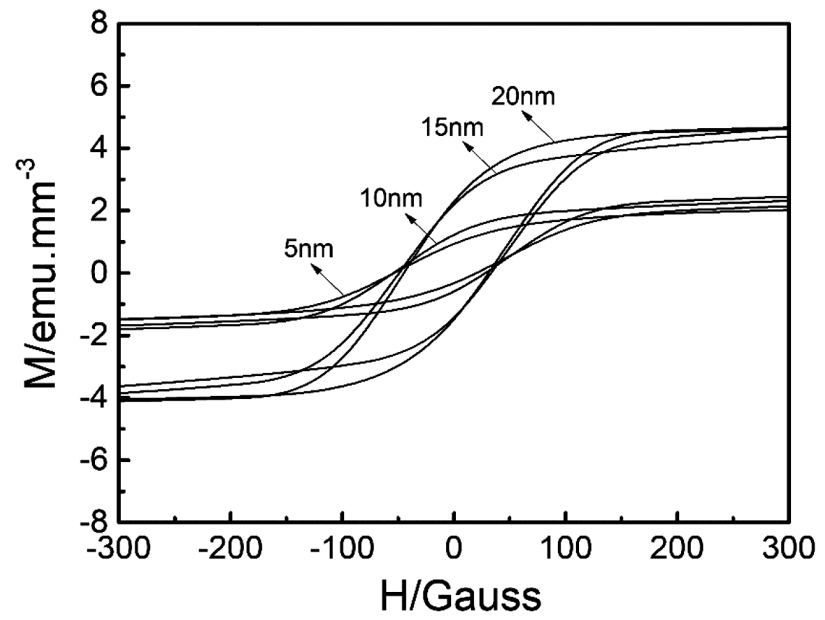

Figure 2: Magnetization hysteresis loops of (5, 10, 15 and 20) nm $\mathrm{Fe}_{65} \mathrm{Co}_{35}$ films

function of voltage no longer exhibits the proportional relation behavior. For instance, for the $10-\mathrm{nm} \mathrm{Fe}_{65} \mathrm{Co}_{35}$ films, when the sweep voltage is $150 \mathrm{mV}$, the current increases steeply from $10 \mu \mathrm{A}$ to above $110 \mu \mathrm{A}$, indicating the presence of the low-resistance state, and as the sweeping voltage increases to $200 \mathrm{mV}$, the current decreases sharply from $110 \mu \mathrm{A}$ to about $10 \mu \mathrm{A}$, indicating that the sample was switched to the high-resistance state and the current changed substantially, proportionally to the voltage. In this regime, the current voltage develops a resistive switching behavior, producing more than an order-of-magnitude change in the resistance. It should be noted that the threshold voltage for the switch of the low-resistance state to the high-resistance state increases from $140 \mathrm{mV}$ to about $300 \mathrm{mV}$ when the film thickness increases from $5 \mathrm{~nm}$ to $20 \mathrm{~nm}$. When a $\mathrm{Fe}_{65} \mathrm{Co}_{35}$ film is in contact with $\mathrm{Si}$, a depletion layer (barrier layer) of carriers is formed on the surface of $\mathrm{Si}$, a surface barrier appears and a region with a rectifying effect is formed. Its volt-ampere characteristic is similar to that of the $p-n$ junction, showing a non-linear state. ${ }^{13}$

Figure 4 shows the Hall resistivity of the $(5,10,15$ and 20) $\mathrm{nm} \mathrm{Fe}_{65} \mathrm{Co}_{35}$ thin films at room temperature in

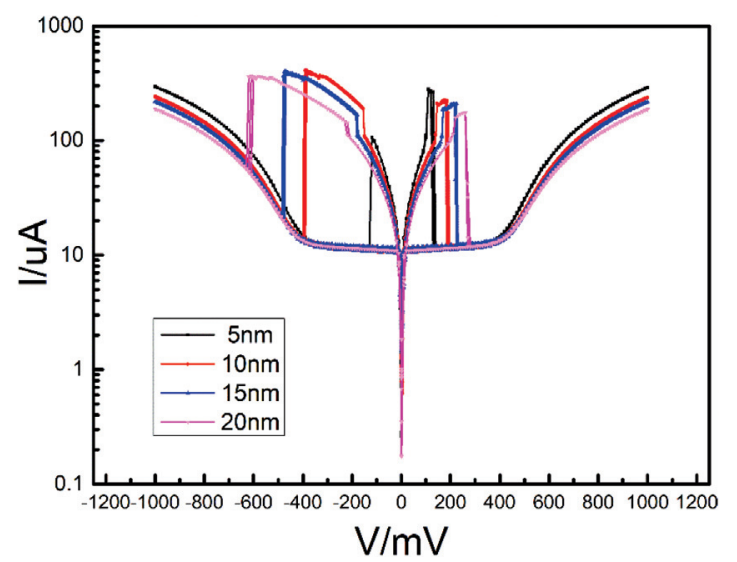

Figure 3: $\mathrm{I}-\mathrm{V}$ behaviors of $\left(5,10,15\right.$ and 20) $\mathrm{nm} \mathrm{Fe}_{65} \mathrm{Co}_{35}$ thin films 


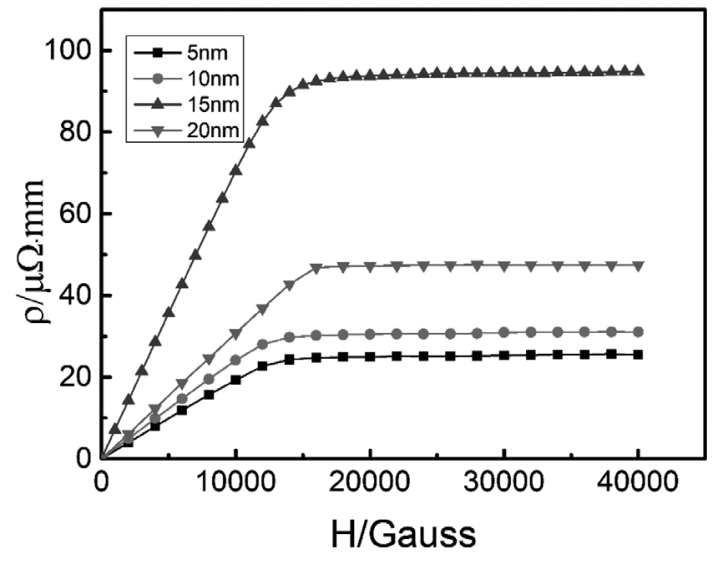

Figure 4: Hall resistivity of $(5,10,15$ and 20$) \mathrm{nm} \mathrm{Fe}_{65} \mathrm{Co}_{35}$ thin films

relation to the applied magnetic field. The anomalous Hall effect is observed for the $\mathrm{Fe}_{65} \mathrm{Co}_{35}$ thin film. The Hall resistivity to be maintained, RHall, is given by the sum of the ordinary Hall effect (OHE) due to the Lorentz force and the anomalous Hall effect (AHE), originating from asymmetric scattering in the presence of magnetization. ${ }^{14}$ It can be seen that the Hall resistivity rises rapidly with the increase of the magnetic-field intensity, which can be caused by the increase of the vertical component of magnetization. When the magnetic field is low, the abnormal Hall effect dominates. When magnetization reaches saturation, the hall resistivity increases linearly with a small slope and approaches saturation, which is caused by the normal Hall effect. ${ }^{15}$ In addition, we measured the carrier density, Hall resistivity, Hall coefficient and mobility of the films of different thicknesses at room temperature as shown in Table $\mathbf{1 .}$

Table 1: Summary of $\mathrm{Fe}_{65} \mathrm{Co}_{35}$ thin films including thickness, temperature, resistivity, coefficient, mobility and type

\begin{tabular}{|c|c|c|c|c|c|}
\hline $\begin{array}{c}\text { Thickness } \\
(\mathrm{nm})\end{array}$ & $\begin{array}{c}\text { Density } \\
\left(1 / \mathrm{cm}^{3}\right)\end{array}$ & $\begin{array}{c}\text { Resistivity } \\
(\Omega * \mathrm{~cm})\end{array}$ & $\begin{array}{c}\text { Coefficient } \\
\left(\mathrm{cm}^{3} / \mathrm{C}\right)\end{array}$ & $\begin{array}{c}\text { Mobility } \\
\left(\mathrm{cm}^{2} / \mathrm{V} / \mathrm{S}\right)\end{array}$ & Type \\
\hline 5 & $1.13 \times 10^{19}$ & $3.30 \times 10^{1}$ & $2.28 \times 10^{-1}$ & $1.42 \times 10^{1}$ & $\mathrm{P}$ \\
\hline 10 & $2.86 \times 10^{19}$ & $1.37 \times 10^{-2}$ & $2.20 \times 10^{-1}$ & $1.60 \times 10^{1}$ & $\mathrm{P}$ \\
\hline 15 & $5.21 \times 10^{19}$ & $1.32 \times 10^{-3}$ & $1.03 \times 10^{-1}$ & $7.81 \times 10^{1}$ & $\mathrm{P}$ \\
\hline 20 & $6.08 \times 10^{19}$ & $1.46 \times 10^{-3}$ & $1.20 \times 10^{-1}$ & $8.18 \times 10^{1}$ & $\mathrm{P}$ \\
\hline
\end{tabular}

The research shows that in ferromagnetic metallic systems, the change in magnetism is often related to the carrier density. ${ }^{16}$ Due to the anomalous Hall effect on the surface of the $\mathrm{Fe}_{65} \mathrm{Co}_{35}$ film, the surface carrier density of the $\mathrm{Fe}_{65} \mathrm{Co}_{35}$ film changed when the Hall-effect test was performed, resulting in magnetic switching.

\section{CONCLUSION}

In summary, ultra-thin $\mathrm{Fe}_{65} \mathrm{Co}_{35}$ metal films were formed using ion-beam deposition on $\mathrm{Si} / \mathrm{SiO}_{2}$ substrates. Under the action of an electric field, electrical-resistance switching and magnetic switching occurred at the nano-level of the surfaces of the $\mathrm{Fe}_{65} \mathrm{Co}_{35}$ thin films. The electric-field-modulated transport behaviors are attributed to the density of the itinerant electrons in the metals.

\section{REFERENCES}

${ }^{1}$ S. J. Pearton, C. R. Abernathy, D. P. Norton, A. F. Hebard, Y. D. Park, L. A. Boatner, J. D. Budai, Advances in wide bandgap materials for semiconductor spintronics, Materials Science and Engineering: R: Reports, 7 (2003) 404

${ }^{2}$ D. P. Sahu, S. N. Jammalamadaka, Remote control of resistive switching in $\mathrm{TiO}_{2}$ based resistive random access memory device, Scientific Reports, 7 (2017), 17224

${ }^{3}$ J. Wang, H. Wang, H. Jiang, X. Wang, Y. Lin, C. W. Nan, Large electric-field modulation of magnetic properties in Fe films on BiScO3-PbTiO3 ceramics, Journal of Nanomaterials, 17 (2010) 42750

${ }^{4}$ G. P. Johari, The electrostatic field and the molecular dipole moment in the polymorphs of ice, The Jounal of Chemical Physics, 80 (2000), 4413-4422

${ }^{5}$ T. Nozaki, Y. Shiota, S. M., S. Murakami, F. Bonell, S. Ishibashi, H. Kubota, K. Yakushiji, T. Saruya, A. Fukushima, S. Yuasa, T. Shinjo, Y. Suzuki, Electric-field-induced ferromagnetic resonance excitation in an ultrathin ferromagnetic metal layer, Nature Physics, 8, (2012), 491-494

${ }^{6}$ Y. Shirahata, R. Shiina, D. López González, K. J. A. Franke, E. Wada, M. Itoh, N. A. Pertsev, S. van Dijken, T. Taniyama, Electric-field switching of perpendicularly magnetized multilayers, NPG Asia Materials, 7 (2015) e198

${ }^{7}$ A. A. Semenov, O. V. Pakhomov, P. Yu. Beliavskiy, A. V. Es'kov, S. F. Karmanenko, A. A. Nikitin, Analysis of the dynamics of electrocaloric response in ferroelectrics using a ferromagnetic resonator, Technical Physics, 11 (2012), 1-57

${ }^{8}$ L. He, Z.-Mi. Liao, H.-C. Wu, X.-X. Tian, D.-S. Xu, Gr. L.W. Cross, G. S. Duesberg, I. V. Shvets, D.-P. Yu, Memory and threshold resistance switching in $\mathrm{Ni} / \mathrm{NiO}$ core-shell nanowires, Nano Letters, 7 (2011) 4601-4606

${ }^{9}$ Y. Hwang, J. Choi, S. C. Hong, S. Cho, S.-H. Han, K.-H. Shin, M.-W. Jung, Y. Hwang, Ferromagnetic ordering in Mn induced by thermal strain, Physical Review B, 79 (2009), 045309

${ }^{10} \mathrm{M}$. Wang, X. Jin, Magnetism in thin film ferromagnets modified by an electric field, Physics, 12 (2009), 0379-4148

${ }^{11}$ C. Song, B. Cui, F. Li, X. Zhou, F. Pan, Recent progress in voltage control of magnetism: Materials, mechanisms, and performance, Progress in Materials Science, 33 (2017) 87

${ }^{12}$ G. C. Hadjipanayis, Magnetic hysteresis in novel magnetic materials, Springer Nature, 47 (1997) 338

${ }^{13}$ J. Pultorak, Influence of the charge carriers recombination and generation at the surface of the depletion layer on the static characteristic of the silicon $\mathrm{p}-\mathrm{n}$ junction, Microelectronics Reliability, 13 (1982) 117

${ }^{14}$ N. A. Sinitsyn, Semiclassical theories of the anomalous Hall effect, Journal of Physics: Condensed Matter, 13 (2008) 202

${ }^{15}$ F. Matsukura, D. Chiba, T. Omiya, E. Abe, T. Dietl, Y. Ohno, K. Ohtani, H. Ohno, Control of ferromagnetism in field-effect transistor of a magnetic semiconductor, Physica E, 12 (2002), 351-355

${ }^{16}$ D. A. Tuan, D. D. Dung, V. T. Son, Y. Shin, S. Cho, Magnetism and transport properties of epitaxial $\mathrm{Fe}-\mathrm{Ga}$ thin films on $\mathrm{GaAs}(001)$, Journal of Applied Physics 111 (2012), 07C517 